\title{
Relationship of Social Media Use (Tik-Tok) With Characters in Junior High School Grade VII in MTsN 2 Bulukumba
}

\author{
Sri Nurul Kurniati $1^{*}$, Fitriani ${ }^{2}$, Haerati ${ }^{3}$ \\ S1 Nursing Study Program Stikes Panrita Husada Bulukumba, Indonesia ${ }^{1}$ \\ Maternity Nursing Department Panrita Husada Bulukumba, Indonesia ${ }^{2}$ \\ Department of Basic and Community Nursing Panrita Husada Bukukumba, Indonesia ${ }^{3}$
}

Correspondent: srinurulkurniati@gmail.com*

\begin{abstract}
ABSTRAK
The current phenomenon shows how social media presents a variety of interesting applications that focus on the existence of its users from various kalanagn. Currently, social media is the most popular of various calendars, especially children, namely Tik-Tok with download data of 63.3 million users, where humans are supported by their character, making individuals have to establish social relationships with the community and social environment. Individual character is defined as behavior that is done consciously so as to form a pattern of habits.. The purpose of this study was to find out the relationshipof Tik-Tok social media use with Character in grade VII junior high school children in MTsN 2 Bulukumba.. In accordance with the problem of descriptive research correlation research methods used in this study are quantative research methods with retrospective cohort research design types that are modifications of cohort design. This design is used to determine the relationship between independent variables (risk factors) and dependent variables (outcomes) based on time travel across from the identification of risk factors to the occurrence of outcomes, but all events occurred in the past (retrospective). The study sampled 48 respondents. The data analysis in this study used the Chi-Square test. . With the statistical test used chi-square test obtained a value $p: 0.449$ which means there is no correlation or relationship of social media use Tik-Tok with character in children of middle age.. The conclusion of this study is the influence of tik-tok social media use on the character of junior high school age children in grade VII in MTsN 2 Bulukumba Bulukumbat district in 2021. Researchers suggest that the results of this study can be used as a reference to apply in the scope of nursing, especially for the character of children.
\end{abstract}

Keywords: Social media, Tik-Tok, Child characters

\section{INTRODUCTION}

Humans are social creatures. Because in essence man is not able to live his life alone and must interact with each other. As the times of the way humans interact began to change, various communication tools have been developed in the current era of globalization that can facilitate humans in interacting. For example, smart phones, which are electronic telecommunication devices, can be said to take many important roles in helping the process of social interaction in the present. The current phenomenon of some social media features available in smart phone applications has taken over a lot of attention from various circles, not only among adults, even from teenagers to children have taken over in the use of social media. 


\section{COMPREHIDNSTV HEALHA CARD}

Social media is a place or media container that prioritizes the existence of each user and facilitates them in activities or collaboration, therefore social media can be interpreted as an online facility that can strengthen the relationship between its users as well as a social bond (Nabila et al,2020). The use of social media today has become one of the most widely used communication tools of the community. Based on data from internet and social media statistics in 2019 in Indonesia according to Hootsuite (2019) social media users with an age range of $13-17$ years as much as $15 \%$, $18-24$ years as much as 33\%, 23-34 years as much as 33\%, 35-44 years as much as 12\%, 45-54 years as much as $4.4 \%$, while $56-64$ years as much as $1.2 \%$. It can be concluded that social media users of children to adolescents reach $15 \%$ of the majority of the Indonesian population (Widia and Faizun, 2019).

Currently the most popular social media feature by many circles, especially among children, is Tik-Tok which is a video application with a short duration. As reported by CNBC Indonesia "Based on TikTok reports, TikTok's active users until July 2020 have reached 689.17 million users. This is an incredible achievement for a 4-year-old stone app launched by Bytedance in 2016. TikTok reported in January 2018 that tiktok's active users only reached 55 million users. At the end of 2018 the number jumped to 271 million users. At the end of 2019 it became 507 million users. TikTok also reports the short video app has been downloaded more than 2 billion times globally. TikTok also reported user growth of close to $800 \%$ since January $2018 "$ as quoted by CNBC, Tuesday $(08 / 25 / 2020)$. Character is terminologically defined as the behavior of a person who is supported by a conscious desire to do an act. Character is the most common assessment in human behavior that includes all activities in life, be it related to creators, individuals, fellow human beings, both with the environment contained in thought, attitudes, individual feelings, words, and actions, which are based on religious norms, laws, manners, culture, and cultural customs

(Sitorus, 2018) conducted a study with the title of influence using the Tik-Tokapplication on child sexual abuse (Study on users of Tik-Tokapplication in teenagers of Medan city). The results of his research explained that there is an influence on the use of Tik-Tokapplication on the behavior of adolescents in the city of Medan. The interest or interest of medan city teenagers towards the TikTokapplication because the features in the Tik-Tokapplication are so varied and diverse that video creation can be done with interest.

With the large amount of data on tiktok application downloads that are currently reported from several national and international media researchers took the initiative to see how the influence of TikToksocial media on character formation in children. Considering that nowadays it is 
very rare for people who do not use social media even children. By using TikTok social media someone can express himself at will, this is the reason for TikTokusers.

\section{MATERIALS AND METHODS}

In accordance with the problem of descriptive research correlation research methods used in this study are quantative research methods with retrospective cohort research design types that are modifications of cohort design. This design is used to determine the relationship between independent variables (risk factors) and dependent variables (outcomes) based on time travel across from the identification of risk factors to the occurrence of outcomes, but all events occurred in the past (retrospective) (Kusuma Dharma, 2011).. The sampling technique used is Nonprobability sampling: Consecutive sampling which is the selection of samples by determining subjects who meet the research criteria included in the study up to a certain period of time, so that the number of samples needed is met (Nursalam, 2017).

The instruments used in this study were on independent variables using questionnaires with the Likertscale, while on dependent variables using questionnaires with the Gutman personality type scale will be measured using a scale adapted from the Eysenck Personality Inventory (EPI) compiled by Eysenck (1964). The scores produced by two dimensions, namely Extraversion and Neuroticism will be summed. To determine a person's personality type, the number of scores obtained from each Distribution of responde characteristics by age, gender and class will be scored using the reference to the personality type scale norm from Eysenck.

\section{RESULTS}

Tabel 1.Distribution of responde characteristics by age, gender and class

\begin{tabular}{|c|c|c|}
\hline Characteristics of Respondents & Frekuensi (n) & Percent (\%) \\
\hline \multicolumn{3}{|l|}{ Age } \\
\hline 11-year-old & 18 & 37,5 \\
\hline 12-year-old & 30 & 62,5 \\
\hline \multicolumn{3}{|l|}{ Gender } \\
\hline Woman & 26 & 54,2 \\
\hline Man & 22 & 45,8 \\
\hline \multicolumn{3}{|l|}{ Class } \\
\hline VII1-VII4 & 22 & 45,8 \\
\hline VII5-VII8 & 26 & 54,2 \\
\hline Amount & 48 & 100 \\
\hline
\end{tabular}




\section{COMPREHENSTVE HEALHH CARE}

Based on table 1. with the number of respondents 48 people showed that the proportion of respondents aged 12 years (62.5\%) more than respondents aged 11 years (37.5\%) with most respondents having a female gender as many as 26 respondents (54.2\%) compared to male respondents as many as 22 respondents (45.8), respondents from class VII5-VII8 as many as 26 people (54.2\%) more than respondents from class VII1-VII4 as many as 22 people (45.6\%).

Tabel 2. Distribution of Tik-Tok social media use

\begin{tabular}{lcc}
\hline Use of Tik-Tok social media & $\mathbf{N}$ & Percentage (\%) \\
\hline Often & 29 & $60,4 \%$ \\
Infrequently & 19 & $39,6 \%$ \\
\hline \multicolumn{2}{c}{ Amount } & $\mathbf{4 8}$
\end{tabular}

Based on the table above with the number of respondents as many as 48 people showed that most of the respondents more often use tik-tok social media as many as 29 respondents (60.4\%) compared to respondents who rarely use tik-tok application as many as 19 respondents (39.6\%)

Tabel 2. Character Distribution After Using Tik-Tok App

\begin{tabular}{|c|c|c|}
\hline Characters After Use & $\mathbf{N}$ & $\%$ \\
\hline Ekstrovert & 38 & 79,2 \\
\hline Introvert & 10 & 20,8 \\
\hline Amount & 48 & 100 \\
\hline
\end{tabular}

Based on the table above with the number of respondents as many as 48 people showed that most of the respondents after using tik-tok social media more have extroverted character as many as 38 respondents (79.2\%) compared to extrovert character as many as 10 respondents (20.8\%)

Tabel 3. Tik-Tok's social media relationship with child characters

\section{Child Characters after using Tik-Tok social media}

Use of Tik-Tok

social media

Ekstrovert Introvert

Sum

Value $\mathrm{p}$

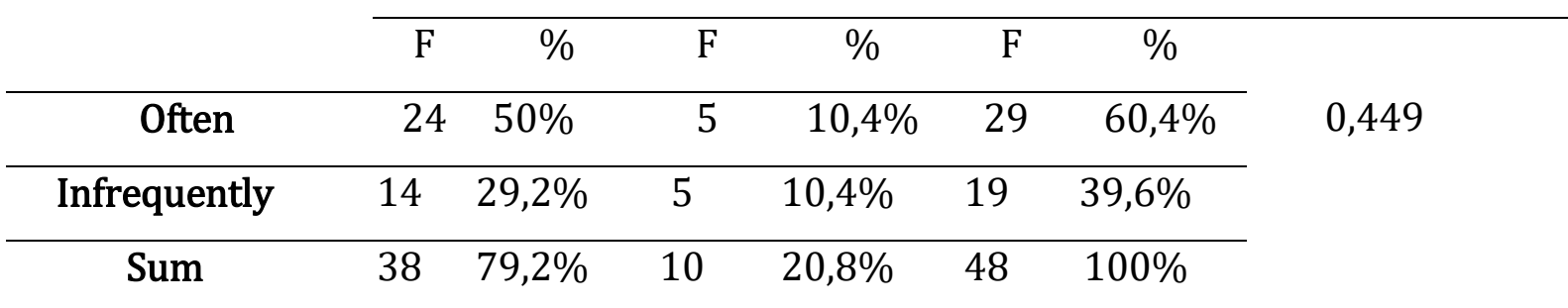

Table 4, shows that students(i) who often use Tik-Tok social media have more extroverted character as many as 24 respondents (50\%) while students (i) who rarely 
use Tik-Tok social media who have introverted character as many as 14 respondents (29.2\%), there are also students (i) who often use tik-tok social media have introverted character as many as 5 respondents (10.4\%) also students (i) who rarely use tik-tok social media have introverted characters. Yak 5 respondents (10.4\%) by using or using Tik-Tok social media showed differences in the character of students (i) who often and rarely use Tik-Tok social media. This shows a difference in the proportion of characters between students (i) who often and rarely use Tik-Tok social media. The results of the Chi-Square Test obtained a value of $p=0.449>0.05$, so it was concluded that there was no correlation between the use of Tik-Tok social media and the character of children. Or to say, tik-tok's use of social media has no connection to character in middle schoolaged children.

\section{DISCUSSION}

The Chi-Square Test result was obtained a value of $p=0.449>0.05$, which means there is no correlation between the use of Tik-Tok social media and the character of children. The number of students(i) who often use Tik-Tok social media has more extroverted character by $50 \%$ while students (i) who rarely use Tik-Tok social media who have an introverted character of $29.2 \%$, there are also students (i) who often use tik-tok social media have an introvert character of $10.4 \%$ and students (i) who rarely use social media Tik-Tok has an introvert character of $10.4 \%$ by using or using social media. Tik-Tok shows the difference in character of students (i) who often and rarely use Tik-Tok social media. This shows a difference in the proportion of characters between students (i) who often and rarely use Tik-Tok social media. This is supported by the theory (Dr. Zubaedi, 2017) that individuals in social interactions mostly react to form certain attitude patterns towards various psychological objects they face such as personal experiences, culture, others that are considered important, emotional factors in individuals and social media.

The results of this study are also in line with research conducted by (Harrison et al.,2017) with a type of qualitative research involving 10 respondents to be interviewed. This explains that along with the various behaviors and responses of individuals associated with the digital world, tiktok is currently being used, it is certainly important to interpret how it should behave or behave properly and properly. And not infrequently also in addition to the negative value of the TikTok application is very vulnerable to causing an impact on its users. The results of the study are that there are 
positive and negative influences of the use of the TikTok application on student behavior.

The researchers' assumption is that the use of Tik-Tok social media in various circles can have an impact on the character of individuals. The use of Tik-Tok social media that is done continuously with a long use time will give new habits to its users. Not satisfied the character that previously existed in the individual will change due to self-habituation that has been done. The character of an individual who was once an extrovert will turn into an introvert if he does new habits that are quite intense for a long time. The character of each different individual makes the changes experienced by each individual is also different, some can survive with the character that was previously owned by maintaining the habits carried out long ago, where changes in behavior and character are influenced by several factors. The age of children 11-12 years where at this time, when viewed from character development, children easily experience changes in behavior and character along with the usual activities children do continuously, because children who enter early adolescence begin to experience many physical and emotional changes so that the child's mood at this stage often changes that make them easily affected both in terms of sight, opinions, as well as the surrounding environment. Women's emotional changes are higher than men's, which is why more women are more likely to seek entertainment to shift their emotional changes, one of which is by playing Tik-Tok social media.

\section{CONCLUSIONS AND SUGGESTIONS}

\section{CONCLUSION}

There are two types of characters that individuals have, namely extroverts and introverts, before students (i) MTsN 2 Bulukumba use social media Tik-Tok introvert characters are more dominant than extrovert characters. After students(i) MTsN 2 Bulukumba who use Tik-Tok social media with frequency often have more extroverted characters are lowered with those students(i) who rarely use.. Tik-Tok's use of social media had no correlation with the respondent's character. The Chi-Square Test results obtained a value of $p=0.449>0.05$, so it was concluded that there was no correlation between the use of Tik-Tok social media and the character of children. 


\section{COMPREALENSIVE HEALHA CARE-}

\section{SUGGESTION}

It is expected to provide information, knowledge, to students (i) about the impact and effects of social media use and increase activities in schools that can divert students (i) not to use social media continuously.. It is expected that at the current age of the child the need for guidance, assistance and restrictions on children in accessing and using social media to avoid the negative effects of their use. It is expected that health workers are more active in increasing knowledge related to the character of children this is to help educate parents in the formation of children's character.

\section{REFERENCES}

Adawiyah, D.P.R. (2020) 'Influence of TikTok Application Use on Adolescent Confidence in Sampang Regency', Communication Journal,14(2), pp. 135-148. doi:10.21107/ilkom.v14i2.7504.

Aprilian, D., Elita, Y. and Afriyati, V. (2019) 'RELATIONSHIP BETWEEN TIKTOK APP USE AND NARCISSISM BEHAVIOR IN HIGH SCHOOL STUDENTS', 2(3), p. 9.

Dewi, E.R. (2020) 'Social Media Relationships in Child Character Formation', Indonesian Journal of Learning Education and Counseling,3(1). doi:10.31960/ijolec.v3i1.586.

Dr. Zubaedi, M.Ag., M.Pd. (last) (2017) TACTICAL STRATEGY OF CHARACTER EDUCATION. Depok: PT RAJAGRAFINDO PERSADA.

Harrison, H. et al. (2017) 'Case Study Research: Foundations and Methodological Orientations', Forum Qualitative Sozialforschung / Forum: Qualitative Social Research,Vol 18, p. No. 1 (2017). doi:10.17169/FQS-18.1.2655.

Husain, B. and Ibrahim, I. (2019) 'Differences in Students' English Learning Achievements Reviewed from Introverted and Extrovert Personality Types', Qalam: Journal of Educational Sciences,7(2), p. 91. doi:10.33506/jq.v7i2.371.

Idea, P. (2007) INNER HEALING In The Office. Jakarta: PT Elex Media Komputindo.

Junaedi, M.Ag., Dr.M. (2017) New Paradigm of Islamic Education Philosophy. Depok: KENCANA.

Kusuma Dharma, K. (2011) Nursing Research Methodology (Guidelines for Implementing and Implementing Research Results). Jakarta: Trans Info Media.

Loehken, S. (2016) Quiet Impact Doesn't Matter Being introverted. Jakarta: PT Gramedia Pustaka Utama. 
Media, K.C. (no date) How Long Does It Take to Change Habits? Page all, KOMPAS.com. Available at: https://sains.kompas.com/read/2018/06/12/203600823/berapalama-waktu-yang-dibutuhkan-untuk-mengubah-kebiasaan- $\quad$ (Accessed: 28 January 2021).

Nabila, D. et al. (2020) SOCIAL MEDIA CIVILIZATION IN THE INDUSTRIAL ERA 4.0. Malang: Communication Science Study Program, University of Muhammadiyah Malang.

Ningsih, Y. and Djollong, A.F. (no date) 'INFLUENCE OF INSTAGRAM USE ON CHARACTER FORMATION', p. 13.

Nursalam (2017) Methodlogy of Nursing Science Research. 4th edn. jakarta: salemba Medika.

Prof. Dr. H. Djaali (last) (2017) EDUCATIONAL PSYCHOLOGY. Jakarta: PT Bumi Aksara.

Prof. Dr. Sugiyono (2018) QUANTITATIVE RESEARCH METHODS. Bandung: ALFABETA, cV.

Prof. Dr. Sugiyono (last) (2020) QUALITATIVE QUANTITATIVE RESEARCH METHODS. Bandung: ALFABETA, cv.

Son, M.F.A. et al. (no date) 'Effect of Tik Tok Application Use On Adicted Behavior of SLTA Students in Pekanbaru City', p. 11.

Princess, W.S.R., Nurwati, N. and S., M.B. (2016) 'INFLUENCE OF SOCIAL MEDIA ON ADOLESCENT BEHAVIOR', Research Proceedings and Community Service,3(1). doi:10.24198/jppm.v3i1.13625.

Rosida, E.R. and Astuti, T.P. (2015) 'DIFFERENCES IN PEER ACCEPTANCE REVIEWED FROM EXTROVERT AND INTROVERT PERSONALITY TYPES', 4, p. 5.

Sriyanto, - et al. (2014) 'Assertive Behavior and Tendencies of Juvenile Delinquency Based on Parenting and the Role of Mass Media', Journal of Psychology,41(1), p. 74. doi:10.22146/jpsi.6959.

Widia, R.A. and Faizun, Q. (2019) 'INFLUENCE OF SOCIAL MEDIA USE ON STRENGTHENING ADOLESCENT CHARACTER', p.

Widiantari, K.S. and Herdiyanto, Y.K. (2013) 'Difference in Intensity of Communication Through Social Networks between Extroverts and Introverts in Adolescents', Udayana Psychology Journal,1(1). doi:10.24843/JPU.2013.v01.i01.p11. 